\title{
Choice of Suitable Economic Adsorbents for the Reduction of Heavy Metal Pollution Load
}

\author{
Shabbir Hussain ${ }^{1 *}$, Muhammad Amin Abid², Khurram Shahzad Munawar, \\ Aisha Saddiqa ${ }^{5}$, Muhammad Iqbal ${ }^{6}$, Muhammad Suleman ${ }^{7}$, Mazhar Hussain $^{6}$, \\ Muhammad Riaz ${ }^{3 * *}$, Tauqeer Ahmad ${ }^{3,4}$, Anees Abbas ${ }^{4}$, \\ Mehrine Rehman ${ }^{8}$, Muhammad Amjad $^{1}$
}

${ }^{1}$ Department of Chemistry, Lahore Garrison University, DHA Phase VI, Lahore, Pakistan

${ }^{2}$ Department of Chemistry, University of Sahiwal, Sahiwal, Pakistan

${ }^{3}$ Department of Chemistry, University of Sargodha, Sargodha, Pakistan

${ }^{4}$ Department of Chemistry, University of Mianwali, Mianwali, Pakistan

${ }^{5}$ Department of Chemistry, Government College University Lahore, Lahore, Pakistan

${ }^{6}$ Department of Chemistry, Government College University Faisalabad, Faisalabad, Pakistan

${ }^{7}$ Department of Chemistry, Riphah International University Faisalabad, Pakistan

${ }^{8}$ Department of Chemistry, Quaid-i-Azam University, Islamabad, Pakistan

Received: 25 March 2020

Accepted: 6 July 2020

\begin{abstract}
Heavy metals e.g., $\mathrm{Hg}, \mathrm{Cd}, \mathrm{Cr}, \mathrm{Pb}, \mathrm{Zn}$, As and $\mathrm{Ni}$ etc are a major sources of pollutants which enter into the food chains and cause serious health impairments, carcinogenicity and mutagenesis. They have adverse effects on blood composition, lungs, energy level, kidneys, central nervous system, liver, and other vital organs of the body. Heavy metals can be successfully removed by easily available, eco-friendly and low-cost adsorbents which include the wastes/products of natural (chitin, silicate porous material, clay and zeolites, vermiculite, cyclodextrin, chitosan, starch and its derivatives, alginates, fly ash), agricultural (walnut shell, Turkish coffee, waste tea, black gram, neem bark, coconut shell, coconut husk, coal, oil palm shell, sugarcane bagasse, rice, wool, waste tea, peat moss, Turkish coffee, exhausted coffee, crop biomass, rice straw, rice hulls, rice husk, rice, soybean hull, papaya wood, peanut shell, peanut, citrus fruits, palm date pits, black gram, wool, cassava waste, carrot residues, banana and orange peels, sugar-beet pectin gels, black gram husk) and industrial (waste rubber tire, waste slurry, lignin, fly ash, red mud)) origin. The adsorption efficiency is affected by functional groups and particle/ pore size of the adsorbent, speed of agitation, biosorbent dose, initial concentration and molecular size of metal ions, temperature and $\mathrm{pH}$.
\end{abstract}

Keywords: heavy metals, adsorbents, agricultural, natural, industrial

*e-mail: dr.shabbirhussain@1gu.edu.pk

**e-mail: riaz_453@yahoo.com 


\section{Introduction}

Water is necessary for human beings, plants and animals. However, water pollution has become a major issue these days due to mixing of urban, agricultural and industrial wastes in it $[1,2]$. Tremendous quantities of wastewater containing heavy metals (like $\mathrm{Cu}$, $\mathrm{Hg}, \mathrm{As}, \mathrm{Cd}, \mathrm{Cr}, \mathrm{Pb}, \mathrm{Zn}$ and $\mathrm{Ni}$ etc.) are released by industries (like photographic film production, petroleum refining, wood processing units, electroplating, paint, dyes, pigments, textile, tannery, leather) into the aquatic environment and enter into the food chains resulting in carcinogenicity, mutagenesis and many other adverse effects [3-6]. Their toxicity and mobility in an aqueous system greatly affect vegetation, animals and human beings [7]. So it has become necessary to adopt appropriate strategies for the reduction of heavy metal's concentration in water to an acceptable level [8]. Although different procedures e.g., ion exchange, reverse osmosis, electro-dialysis, membrane separation, chemical oxidation, chemical precipitation [9], anaerobic biotechnology [10], membrane filtration, evaporation and precipitation [11] are applied to remove the heavy metals, the adsorption has attracted greater attention due to its low-cost, high efficiency, design flexibility, eco-friendly nature and easy availability of adsorbents [12].

Current studies were performed to overview various adsorption strategies that are applied to eliminate heavy metals from wastewater.

\section{Pollution Load of Heavy Metals and Its Hazardous Effects}

Heavy metals are essential nutrients and play a vital role in healthy lives of people; however, they are toxic in excessive concentrations. The heavy metals are generally present in vegetables, fruits and in multivitamin products. They are also are part of residual wastes of batteries, pesticides, alloys, textile dyes, steel [13]. Their higher concentrations may lead to allergies and cancer and also causes adverse effects on blood composition, liver, lungs, energy level, kidneys, central nervous system etc. Long-term exposure to heavy metals may lead to neurological, physical and muscular degenerative processes which may result in Alzheimer's disease, muscular dystrophy, Parkinson's disease, multiple sclerosis etc. [13]. Table 1 summarizes some sources and toxic effects of common heavy metals.

\section{Adsorption Processes}

Adsorption is a renowned equilibrium separation process which involves the adsorbents of biological, organic or mineral nature [20]. These adsorbents include clays, zeolites, silica beads, activated carbons, biomass, agricultural wastes, industrial by-products and numerous polymeric materials [21]. Based upon the nature of intermolecular forces, adsorption is classified into physical and chemical categories.

Table 1. Sources of heavy metals and their toxicological effects.

\begin{tabular}{|c|c|c|c|c|}
\hline Heavy metals & $\begin{array}{l}\mathrm{MCl}^{*} \\
(\mathrm{mg} / \mathrm{L})\end{array}$ & Sources & Toxicity & $\begin{array}{l}\text { Ref } \\
\text { No. }\end{array}$ \\
\hline $\begin{array}{l}\text { Arsenic } \\
\text { (As) }\end{array}$ & 0.05 & $\begin{array}{l}\text { Pesticides, fungicides, metal smelters, tobacco } \\
\text { smoke, combustion of coal, production of steel } \\
\text { and iron, nickel and copper }\end{array}$ & $\begin{array}{l}\text { Bronchitis, dermatitis } \\
\text { gastrointestinal damage, severe } \\
\text { vomiting, diarrhea, death }\end{array}$ & {$[4,14]$} \\
\hline $\begin{array}{l}\text { Cadmium } \\
\quad(\mathrm{Cd})\end{array}$ & 0.01 & $\begin{array}{l}\text { Production of steel and iron, sludge, paints, } \\
\text { incinerations, combustion of coal and fuel }\end{array}$ & $\begin{array}{l}\text { Reproductive system, fertility, kidney } \\
\text { damage, renal disorder, carcinogenic }\end{array}$ & [15] \\
\hline $\begin{array}{c}\text { Lead } \\
(\mathrm{Pb})\end{array}$ & 0.006 & $\begin{array}{l}\text { Mining and burning of coal, emissions from } \\
\text { automobile, pesticides, paint }\end{array}$ & $\begin{array}{c}\text { Mental illness in children, } \\
\text { gastrointestinal problems, liver and kidney } \\
\text { damage }\end{array}$ & [6] \\
\hline $\begin{array}{l}\text { Chromium } \\
\text { (Cr) }\end{array}$ & 0.05 & Steel and textile industry & $\begin{array}{c}\text { Headache, diarrhea, nausea, vomiting, } \\
\text { carcinogenic }\end{array}$ & [14] \\
\hline $\begin{array}{l}\text { Mercury } \\
(\mathrm{Hg})\end{array}$ & 0.00003 & $\begin{array}{l}\text { Pesticides, batteries, paper, pulp, solid waste } \\
\text { combustion, smelting, mining, fossil fuel } \\
\text { combustion }\end{array}$ & Nervous system is affected badly & {$[16]$} \\
\hline $\begin{array}{l}\text { Zinc } \\
(\mathrm{Zn})\end{array}$ & 0.80 & Metal plating, brass manufacture, refineries & $\begin{array}{l}\text { Effects on nervous system. Zinc fumes } \\
\text { cause skin problems }\end{array}$ & {$[17]$} \\
\hline $\begin{array}{l}\text { Copper } \\
(\mathrm{Cu})\end{array}$ & 0.25 & $\begin{array}{l}\text { Copper water heaters, water pipes, alcoholic } \\
\text { beverages from copper brewery equipment, } \\
\text { copper in canned greens and frozen greens to } \\
\text { produce ultra-green color }\end{array}$ & $\begin{array}{l}\text { Liver damage, Wilson disease, } \\
\text { Insomnia, gastrointestinal problems }\end{array}$ & {$[18]$} \\
\hline Nickel (Ni) & 0.20 & $\begin{array}{l}\text { Effluents of silver refineries, storage battery } \\
\text { industries, electroplating, zinc base casting }\end{array}$ & $\begin{array}{l}\text { Dermatitis, nausea, chronic asthma, } \\
\text { coughing, human carcinogen, } \\
\text { reproductive effects, respiratory cancer }\end{array}$ & [19] \\
\hline
\end{tabular}

${ }^{*} \mathrm{MCl}=$ Metal chloride 
Physical adsorption involves the binding of adsorbates on to the surface of adsorbents by van der Waals forces. The electronic structures of atoms and molecules are almost not disturbed in physical adsorption. Physical adsorption is favored at specific $\mathrm{pH}$ conditions under the low-temperature atmosphere [9, 14]. In chemical adsorption (also called activated adsorption), the adsorbent and adsorbate chemically react with each other resulting in a strong interaction (covalent or ionic) between both. The adsorbate which has the ability to make a monolayer is used in the catalysis. Generally, a pollutant is adsorbed on to the solid adsorbent in 3 main steps: (i) Transfer of pollutants to external surface of an adsorbent from bulk solution (ii) Mass transfer by pore diffusion to inner surface of porous structure from outer surface of adsorbent (iii) Adsorption of adsorbate on to active sites of adsorbent pores [9, 14]. Adsorption is associated with several advantages which include: (a) metal recovery (b) absence of toxic sludge generation (c) regenerative (d) metal selectivity (e) inexpensive and (f) most significantly effective. The wastewater contaminated with heavy metals can be treated by applying low-cost adsorbents (e.g., modified biopolymers, natural materials, industrial byproducts or agricultural wastes) [9].

\section{Natural Materials as Adsorbents}

Natural materials are considered as low-cost adsorbents; they are environment-friendly and available in large quantities [22]. Biosorption by plant leaves is an environment-friendly technique for elimination of heavy metals from an aqueous environment and is applied worldwide [23]. The adsorbents of natural origin e.g., chitin, peat moss, clay and zeolites show an efficient removal of toxic heavy metals including $\mathrm{Cd}, \mathrm{Cr}, \mathrm{Hg}, \mathrm{Ni}, \mathrm{Zn}, \mathrm{Cu}, \mathrm{Pb}$ [9]. Recently attempts are being made to develop more effective and cheaper adsorbents containing natural polymers for example cyclodextrin [24], chitosan [25], starch and its derivatives [26], alginates [27] etc. The natural polymers like polysaccharides are biodegradable, renewable and abundantly available and have natural ability to associate physically or chemically with a large variety of molecules. Hence polysaccharides are considered as excellent low-cost adsorbents for water decontamination. Alginates are commercially attractive polysaccharide biopolymers due to their excellent potential for the formation of complexes with various metals [28]. There are many other natural biosorbents which have tendency to eliminate heavy metals from wastewater. Tea is the mostly consumed beverage

Table 2. Low-cost natural adsorbents used to remove metals.

\begin{tabular}{|c|c|}
\hline Natural adsorbent & Metals removal capacity \\
\hline Peat moss-derived biochars & $\mathrm{Cu}(18.2 \mathrm{mg} / \mathrm{g}), \mathrm{Cd}(39.8)$ and $\mathrm{Pb}(81.3 \mathrm{mg} / \mathrm{g})[30]$ \\
\hline Zeolite & $\begin{array}{c}\mathrm{Pb}^{2+} \text { and } \mathrm{Cd}^{2+}(175 \text { and } 137 \mathrm{mg} / \mathrm{g} \text {, respectively) [31] } \\
\text { For cobalt }-0.011 \mathrm{mg} \text {-equ/L; for nickel }-0.020 \mathrm{mg} \text {-equ/L; for iron }-0.021 \mathrm{mg} \text {-equ/L; } \\
\text { for copper }-0.023 \mathrm{mg} \text {-equ/L [32] }\end{array}$ \\
\hline $\begin{array}{l}\text { Silicate porous material } \\
\text { (SPM) }\end{array}$ & $\mathrm{Cu}^{2+}, \mathrm{Cd}^{2+}$ and $\mathrm{Pb}^{2+}(32.26 \mathrm{mg} / \mathrm{g}, 35.36 \mathrm{mg} / \mathrm{g}$ and $44.83 \mathrm{mg} / \mathrm{g}$, respectively) [33] \\
\hline Chitosan-based sorbents & $\begin{array}{l}\text { (i) With functionalized chitosen (CH)-based biosorbent, } \mathrm{Pb}^{2+}, \mathrm{Cd}^{2+} \text { and } \mathrm{Cu}^{2+}(1.60,1.96,2.82 \mathrm{mg} / \mathrm{g} \text {, } \\
\text { respectively) [34] } \\
\text { (ii) With xanthated chitosen, the removal rate reached upto } 99.1 \%, 100 \% \text { and } 100 \% \text { for } \mathrm{Cd}^{2+}, \mathrm{Cu}^{2+} \text { and } \\
\qquad \mathrm{Cr}^{3+} \text {, respectively [35] } \\
\text { (iii) Arginine cross-linked chitosan-carboxymethyl cellulose beads can remove } 168.5 \\
\text { and } 182.5 \mathrm{mg} \mathrm{g} \text { of } \mathrm{Cd}(\mathrm{II}) \text { and } \mathrm{Pb}(\mathrm{II}) \text { ions, respectively [36] } \\
\text { (iv) Chitosan-coated sour cherry kernel shell beads can remove } 24.492 \mathrm{mg} \mathrm{g}^{-1} \mathrm{Cr}(\mathrm{VI}) \text { [37] }\end{array}$ \\
\hline $\begin{array}{l}\text { Clay minerals and metal } \\
\text { oxides }\end{array}$ & Cr, TI, Th, Mo, Eu, V, Mn, Cs, Ga, Cr, Cd, As, In, Hg, Pb, V, Zn, Cu, Co, Ni, As, In [38] \\
\hline Vermiculite & $\begin{array}{l}\mathrm{Cu}(\mathrm{II}) \text { removal up to } 67.6 \% \text { at the agitation speed of } 400 \mathrm{rpm} \text { and ambient temperature. } \\
\text { It is about } 42.5 \% \text { at } 60^{\circ} \mathrm{C} \text { without agitation [39] }\end{array}$ \\
\hline Sepiolite & $\begin{array}{c}\mathrm{Cd}\left(\mathrm{II}<\mathrm{Mn}(\mathrm{II})<\mathrm{Fe}(\mathrm{III})<\mathrm{Co}(\mathrm{III}) \sim \mathrm{Cu}(\mathrm{II})<\mathrm{Zn}(\mathrm{II}) \text { with affinities of } 0.445 \times 10^{-4}, 0.979 \times 10^{-4}, 1.193 \times 10^{-4},\right. \\
1.865 \times 10^{-4}, 1.870 \times 10^{-4} \text { and } 2.167 \times 10^{-4} \mathrm{~mol} \mathrm{~g}^{-1} \text { respectively }[40] .\end{array}$ \\
\hline Pumice & $\begin{array}{l}1.15 \mathrm{mg} / \mathrm{g} \text { of } \mathrm{Zn} \text { uptake. The modified pumice }\left(\text { at } 300^{\circ} \mathrm{C} \text { and soaked with } \mathrm{HCl} \text { ) can remove zinc up to }\right. \\
1.24 \mathrm{mg} / \mathrm{g} \text { [41]. }\end{array}$ \\
\hline Iron-ore-sludge & $\begin{array}{l}\text { Adsorption was found in the order of } \mathrm{Pb}>\mathrm{As}>\mathrm{Cd}>\mathrm{Zn}>\mathrm{Mn} \text {; it was ranging either from } 0.370 \mathrm{mg} / \mathrm{g} \text { to } \\
1.059 \mathrm{mg} / \mathrm{g} \text { with mixed-metal solutions or from } 0.710 \mathrm{mg} / \mathrm{g} \text { to } 1.113 \mathrm{mg} / \mathrm{g} \text { with single-metal solutions } \\
{[44]}\end{array}$ \\
\hline Other low-cost adsorbents & $\begin{array}{c}\text { Chitosan }\left(250.273 .815 \mathrm{mg} / \mathrm{g} \text { of and } \mathrm{Cd}^{2+}, \mathrm{Cr}^{2+} \text { and } \mathrm{Hg}^{2+} \text {, respectively); zeolites }(137 \text { and } 175 \mathrm{mg} / \mathrm{g} \text { of }\right. \\
\mathrm{Cd}^{2+} \text { and } \mathrm{Pb}^{2+} \text {, respectively); waste slurry }\left(540,560,1030 \mathrm{mg} / \mathrm{g} \text { of } \mathrm{Cr}^{6+}, \mathrm{Hg}^{2+} \text { and } \mathrm{Pb}^{2+} \text {, respectively); }\right. \\
\text { Lignin }\left(1865 \mathrm{mg} / \mathrm{g} \text { of } \mathrm{Pb}^{2+}\right)[31]\end{array}$ \\
\hline
\end{tabular}


worldwide. With greater production and consumption, a large quantity of tea is discarded in the environment. Tea waste is getting much attention from researchers these days because it is an excellent biosorbent for removal of iron, chromium, nickel and lead [29]. Table 2 shows some low-cost natural adsorbents used to remove metals by adsorption phenomenon.

\section{Adsorption by Agriculture/Plant/Animal Wastes}

The application of agricultural by-products in bioremediation of heavy metals is called biosorption [43]. Metal ions can be recovered from an aqueous environment by using agricultural-by-products which are biodegradable and have no adverse effects on the environment. The use of agro-products as alternatives to conventional adsorbents has been gaining popularity [44]. Such products also have the advantages of cost effectiveness, engineering applicability, technical feasibility and local availability [45]. The temperature, speed of agitation, biosorbent dose and initial concentration of the metal ions and $\mathrm{pH}$ are important parameters which significantly affect the biosorption capacity. Biomass can also be modified physically or chemically before its use as adsorbent. Moreover, the biosorbent can be reused after desorption of heavy metals from it; it makes this process economical [46]. Biosorbents have excellent ability to eliminate toxic heavy metals from effluents and also provide the means of usage of discarded open wastes in wastewater treatment. This procedure demands low investment, less labor and minimal energy input. The efficiency of adsorption is controlled by the particle/pore size of adsorbent, functional groups present on surface of adsorbent, temperature, initial $\mathrm{pH}$ and molecular size of metal ions [47]. Numerous agricultural wastes like walnut shell, Turkish coffee, waste tea, black gram, neem bark, rice husk etc. were investigated to be potent adsorbents of heavy metals [9]. The lowcost agricultural adsorbents like crushed coconut shell and Giridih coal were found suitable for successful elimination of cadmium(II) from aqueous environment depending upon the $\mathrm{pH}$. The chemical interaction and electrostatic forces are responsible for adsorption when $\mathrm{pH}>\mathrm{pH}_{\mathrm{zpc}}$ whereas ion exchange phenomenon occurs when $\mathrm{pH}<\mathrm{pH}_{\mathrm{zpc}}$. However, when the soluble hydroxy complexes are formed above $\mathrm{pH} 10$, the sorption capacity is lowered [48]. There is an extensive usage of activated carbon (AC) in wastewater treatment on commercial level; however $\mathrm{AC}$ remains an expensive material and require the formation of cheaper $\mathrm{AC}$ which are more efficient and environment-friendly [49]. The agro-based inexpensive adsorbents (e.g., coconut shell, rice husk, coconut husk, oil palm shell, rice, wool, waste tea, peat moss, Turkish coffee, exhausted coffee, wall nutshells, crop biomass, rice straw, rice hulls, coconut shell, soybean hull, papaya wood, peanut shell, citrus fruits and sugarcane bagasse) can be used as good alternatives of $\mathrm{AC}[50,51]$. Palm date pits were found to be a cheaper source of activated carbon and were used to eliminate iron, hexavalent $\mathrm{Cr}$ and $\mathrm{Cu}$ from wastewater of an electroplating unit and a tannery. The adsorption of heavy metals took place very fast during first 30 minutes with achievement of equilibrium in 90 minutes. Important parameters include the optimum $\mathrm{pH}$ (4.5-6.5), particle size $(0.5-0.75 \mathrm{~mm})$ and depth of adsorbent layer $(70-90 \mathrm{~cm})$. The removal efficiency and adsorption capacity were reached up to $89 \% \mathrm{Fe}$, $61.65 \% \mathrm{Cr}^{+6}$ and $82.857 \% \mathrm{Cu}$ for effluents collected of electroplating unit while they were found to be $87.03 \%$ $\mathrm{Fe}, 65.42 \% \mathrm{Cr}^{+6}$ and $85.17 \% \mathrm{Cu}$ for tannery wastewater [52]. Metal ions e.g., selenium, zinc, cadmium, lead etc can be significantly recovered from the waste-water by using agricultural-by-products like potato peels, sawdusts, corn cobs, yam peels, banana peels, plantain peels, orange peels, cassava peels, rice-husks as adsorbents [44]. Papaya seeds were tested to eliminate copper ions from aqueous environment; maximum adsorption $(212 \mathrm{mg} / \mathrm{g})$ was observed with the stirring rate of $350 \mathrm{rpm}$ at $\mathrm{pH} 6$ [53].

Zinc (II) and copper (II) can be eliminated from metal finishing wastewater by low-cost adsorbents including natural zeolite, fly ash and peanut husk charcoal at optimum $\mathrm{pH}$ of 6,8 and 6 , respectively. The natural zeolite required the adsorption time of three hours while fly ash and peanut husk charcoal took 2 hours for the removal of metal. The metal elimination capacity was found in the following order: fly ash $<$ peanut husk charcoal $<$ natural zeolite [54]. $\mathrm{Zn}^{2+}$ adsorption capacity was tested by using cheaper modified adsorbents e.g., byproduct adsorbents (rice husk ash, coal fly ash, lignin, sawdust etc.), biosorbents (marine green macroalgae, algal, algae, cassava waste, carrot residues, banana and orange peels, citrus peels, sugar-beet pectin gels, black gram husk etc.), natural source adsorbents (zeolite, bentonite, clay etc.) and activated carbon. The highest $\mathrm{Zn}^{2+}$ adsorption capacity was $52.91 \mathrm{mg} / \mathrm{g}$ with bentonite, $55.82 \mathrm{mg} / \mathrm{g}$ with cassava waste, $128.8 \mathrm{mg} / \mathrm{g}$ with dry marine green macroalgae, $73.2 \mathrm{mg} / \mathrm{g}$ with lignin and $168 \mathrm{mg} / \mathrm{g}$ with powdered waste sludge [55]. By using groundnut shells as adsorbent, the optimum $\mathrm{Cr}(\mathrm{VI})$ adsorption was observed to be at metal ion concentration of $25 \mathrm{mg} / \mathrm{L}$, adsorbent dose of $2.0 \mathrm{~g} / \mathrm{L}$, temperature of $41.5^{\circ} \mathrm{C}, \mathrm{pH}$ 8 and a contact time of $120 \mathrm{~min}$ [56]. The corncob and coconut shell have shown the adsorption in the order of $\mathrm{Cu}>\mathrm{Pb}>\mathrm{Cr}>\mathrm{Zn}>\mathrm{Ni}>\mathrm{Cd}$, as shown by Freundlich and Langmuir model [57].

Chitin from crab shells is an easily available, economical and efficient biosorbant which was used for adsorption of M(II) (zinc, cadmium, nickel, copper, lead) in batch system. The metal adsorption capacity was found to depend upon the initial concentration of $\mathrm{M}(\mathrm{II})$, biomass dose, contact time and initial $\mathrm{pH}$. The adsorption capacities were found to be 38.46, 40, 43.4, 47.61 and $50\left(\mathrm{mg} \mathrm{L}^{-1}\right)$ for $\mathrm{Cd}(\mathrm{II}), \mathrm{Pb}(\mathrm{II}), \mathrm{Cu}(\mathrm{II}), \mathrm{Ni}(\mathrm{II})$ and $\mathrm{Zn}(\mathrm{II})$, respectively. The positive enthalpy $\left(\Delta \mathrm{H}^{\circ}\right)$ 
Table 3. Some low-cost agricultural adsorbents and the respective metals which can be removed.

\begin{tabular}{|c|c|}
\hline Bio-adsorbents & Adsorbents performance \\
\hline Rice husk and fly ash & $\begin{array}{l}\text { Rice husk has the ability to remove simultaneously nickel, lead and iron whereas fly ash can eliminate } \\
\mathrm{Cd} \text { and } \mathrm{Cu} \text {. They can eliminate heavy metals up to the concentration of } 20-60 \mathrm{mg} / \mathrm{L} \text { from wastewater. } \\
\text { Fig. } 1 \text { represents a schematic diagram showing the step wise removal of } \mathrm{Cu}, \mathrm{Ni} \text { and Fe by rice husk and } \\
\text { fly ash [60]. }\end{array}$ \\
\hline $\begin{array}{l}\text { Byproducts of soybeans, } \\
\text { cottonseed hulls, and rice } \\
\text { straw }\end{array}$ & $\begin{array}{c}\text { Their } \mathrm{Zn}(\mathrm{II}) \text { adsorption capacities }(0.52 \text { to } 0.06 \mathrm{meg} / \mathrm{g}) \text { are in the following order: soybean } \\
\text { hulls }>\text { cottonseed hulls }>\text { rice straw }>\text { sugarcane bagasse. The sugarcane bagasse and rice straw have low } \\
\text { adsorptive capacities }(\leq 0.12 \mathrm{meq} / \mathrm{g})[50,61] .\end{array}$ \\
\hline Groundnut husk & Groundnut husk oxidized with silver treatment, has higher chromium adsorption capacities [62]. \\
\hline $\begin{array}{l}\text { Sawdust (a cheaper } \\
\text { by-product of wood } \\
\text { industry) }\end{array}$ & $\begin{array}{l}\text { Sawdust is very efficient for elimination of } \mathrm{Zn}^{2+} \text { and } \mathrm{Cu}^{2+} \text { ions. The organic compounds } \\
\text { (hemicelluloses, cellulose and lignin) present in saw dust have polyphenolic groups which can attach } \\
\text { heavy metal ions by numerous mechanistic pathways. [63]. }\end{array}$ \\
\hline Waste tea leaves & $\begin{array}{l}\text { Tea waste can remove } 3 \text { toxic metal ions like copper, cadmium and lead from aqueous medium. } \\
\text { The elimination capacities of copper(II), cadmium(II) and lead(II) from aqueous water were observed } \\
\text { to be } 21.02,16.87 \text { and } 33.49 \mathrm{mg} / \mathrm{g} \text {, respectively [64]. }\end{array}$ \\
\hline $\begin{array}{l}\text { Watermelon Shell } \\
\text { (eco-friendly and heaper } \\
\text { biosorbent) }\end{array}$ & $\begin{array}{l}\text { Watermelon shell was tested to eliminate copper (II) from an aqueous enviornment. The monolayer } \\
\text { adsorption potential was observed to be } 111.1 \mathrm{mg} / \mathrm{g} \text { from aqueous media [65]. }\end{array}$ \\
\hline Peanut hulls & $21.7 \pm 9.5 \%$ of arsenic and $88.6 \pm 1.9 \%$ of cadmium removal [66] \\
\hline Peanut husk & Ultrasound assisted chemically activated peanut husk shows 19.6 mg/g of copper adsorption [67] \\
\hline
\end{tabular}

and negative free energy $\left(\Delta \mathrm{G}^{\circ}\right)$ showed the endothermic and spontaneous adsorption [58]. Cr(III) can be adsorbed up to $97.48 \%$ by using fly ash (the solid waste from coal-fired power plants) modified with $20 \mathrm{wt} \%$ of $\mathrm{KOH}$ at $15-20^{\circ} \mathrm{C}$ and a contact time of $120 \mathrm{~min}$ [59]. Table 3 displays some low-cost agricultural adsorbents and the respective metals.

Agricultural wastes can also be modified by chemical or thermal treatment and are abundantly applied as adsorbents due to their excellent potential for heavy metals removal. The metal adsorption capability majorly depends upon the adsorbent characteristics, adsorbate concentration and extent of surface modification. However, it is highly important to consider the key factors such as technical applicability and cost effectiveness during the selection of cheaper adsorbents [9]. The low-cost systems are favored to achieve higher environmental standards worldwide. $\mathrm{Cu}(\mathrm{II})$ is successfully eliminated from the wastewater by using sawdust (a cheap material) as an adsorbent. The elimination efficiency of $\mathrm{Cu}$ (II) is greatly affected by salinity, particle size of the adsorbent, dose, temperature, contact time, $\mathrm{pH}$ and concentration. This process is easier, economically feasible and can utilized for the development of an appropriate wastewater treatment plant [68]. Desorption of $\mathrm{Cr}^{6+}, \mathrm{Zn}^{2+}, \mathrm{Ni}^{2+}$ and $\mathrm{Cu}^{2+}$ is $\mathrm{pH}$ dependent. For $\mathrm{Cr}^{6+}$ ions, desorption occurs with $0.01 \mathrm{M} \mathrm{NaOH}$ in electroplating wastes while desorption of $\mathrm{Zn}^{2+}, \mathrm{Ni}^{2+}$ and $\mathrm{Cu}^{2+}$ ions was found to take place in the presence of $0.01 \mathrm{M} \mathrm{HCl}$ solution [69]. Metal ions can be successfully transferred from their aqueous solution into the Bran and hulls (rice milling byproducts). The $\mathrm{Cr}(\mathrm{III}), \mathrm{Zn}(\mathrm{II}), \mathrm{Cu}(\mathrm{II}), \mathrm{Ni}(\mathrm{II})$ and $\mathrm{Co}(\mathrm{II})$ ions are adsorbed up to $13-27 \%$ at metal ion concentration of $100 \mathrm{mg} / \mathrm{L}$. The defatted, extrusion stabilized rice bran (a byproduct of rice oil extraction) was found to be an excellent chelating agent (cation exchanger) for adsorption of $\mathrm{Cr}^{+3}, \mathrm{Zn}^{+2}$ and $\mathrm{Cu}^{+2}$; the adsorption was lowered for $\mathrm{Co}^{+2}$ and $\mathrm{Ni}^{+2}$ ions. However, it is necessary to ensure the effectiveness of rice bran in column applications and its stability to harsh aqueous treatment before its use on industrial scale. Actually $50 \%$ of cation-exchange capacity of rice bran is lost when it is treated with $\alpha$-amylase, SDS, EDTA and boiled for an hour. Under the same conditions, the carboxymethyl cellulose resin does not lose its cation-exchange ability so further investigations are needed to address such kinds of issues [70]. The arsenic and some other heavy metals can be eliminated from mining wastewater by applying simultaneously the horizontal-subsurface-flow constructed wetland (CW) with Phragmites australis (common reed) and adsorption (with modified iron-ore drainage sludge). A pilot-scale experiment was performed on real wastewater of a $\mathrm{Pb}-\mathrm{Zn}$ mine in northern Vietnam for a period of 4 months with $5 \mathrm{~m}^{3}$ /day constant flow rate. The average removal of $\mathrm{Pb}, \mathrm{Zn}, \mathrm{Cd} \mathrm{Mn}$ and $\mathrm{As}$ was found to be $38.7 \%, 52.9 \%, 79.6 \%, 96.9 \%$ and $80.3 \%$, respectively during this period (4 months) by the combined system with limestone substrate. The removal efficiency of arsenic was further improved by using another constructed wetland substrate laterite. The laterite substrate was found more efficient for arsenic removal whereas limestone substrate in $\mathrm{CWs}$ exhibited greater elimination of $\mathrm{Cd}, \mathrm{Zn}, \mathrm{Zn}$ and $\mathrm{Mn}$ [71]. There were investigations on the sorption capacities, morphology properties and physicochemical characteristics of discarded mushroom-stick biochar (DMB) synthesized 

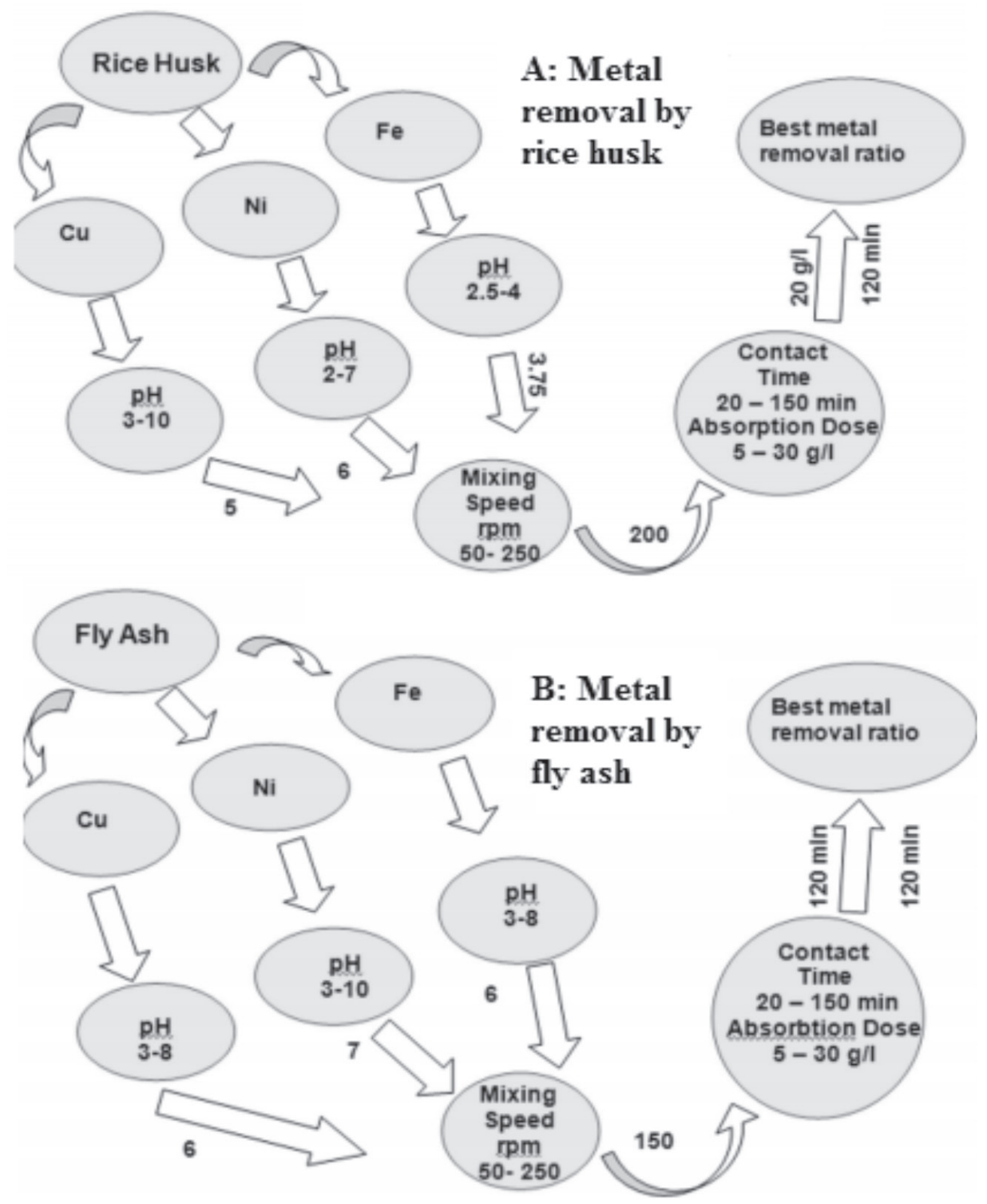

Fig. 1. Schematic Diagram showing the step wise removal of $\mathrm{Cu}, \mathrm{Ni}$ and $\mathrm{Fe}$ by rice husk (A) and fly ash (B) under specific conditions [60].

under various pyrolysis temperatures $\left(300^{\circ} \mathrm{C}\right.$ to $\left.800^{\circ} \mathrm{C}\right)$. The DMB3 (prepared at $300^{\circ} \mathrm{C}$ ) has shown higher yield and surface oxygen-containing group content as compared to that prepared at higher pyrolysis temperatures $\left(500^{\circ} \mathrm{C}\right.$ and $800^{\circ} \mathrm{C}$ ). The DMB8 (prepared at $800^{\circ} \mathrm{C}$ ) has higher polarity, aromaticity, ash content, mineral element and $\mathrm{pH}$. DMB3 has shown higher adsorption capacity (for heavy metals) as compared to DMB5. DMB8 has shown maximal sorption capacities of 21.0, 18.8, 11.2, and $9.8 \mathrm{mg} \mathrm{g}^{-1}$ for $\mathrm{Pb}^{2+}, \mathrm{Cu}^{2+}, \mathrm{Cd}^{2+}$, and $\mathrm{Ni}^{2+}$, respectively. The heavy metal adsorption by DMB depends upon two dominant mechanisms of ion exchange and mineral precipitation and is monitored by the pyrolytic temperature. When pyrolysis temperature is enhanced, then effect of organic components on sorption of heavy metals is decreased whereas the effect of minerals is enhanced. The use of discarded mushroomsticks in the production of efficient biochars provides an efficient path of removing the mixed heavy metals from wastewater. The study provides the way of recycling of discarded mushroom-sticks and their conversion into efficient metal adsorbents and potential use of agriculture waste [72]. Mixed waste tea and coffee ground tea are excellent environmentfriendly biosorbents for elimination of $\mathrm{Cr}(\mathrm{VI})$ from an aqueous medium [73]. The adsorption capacities with agricultural waste composite-activated carbon were observed to be 200 and $250 \mathrm{mg} / \mathrm{g}$ for $\mathrm{As}(\mathrm{III})$ and $\mathrm{Pb}$ (II), respectively with the BET surface area of 849.630 and $230.242 \mathrm{~m}^{2} / \mathrm{g}$ [74].

\section{Adsorption by Industrial Wastes/Products}

The toxic heavy metals can be successfully eliminated from the contaminated water by numerous low-cost industrial byproducts such as grape stalk 


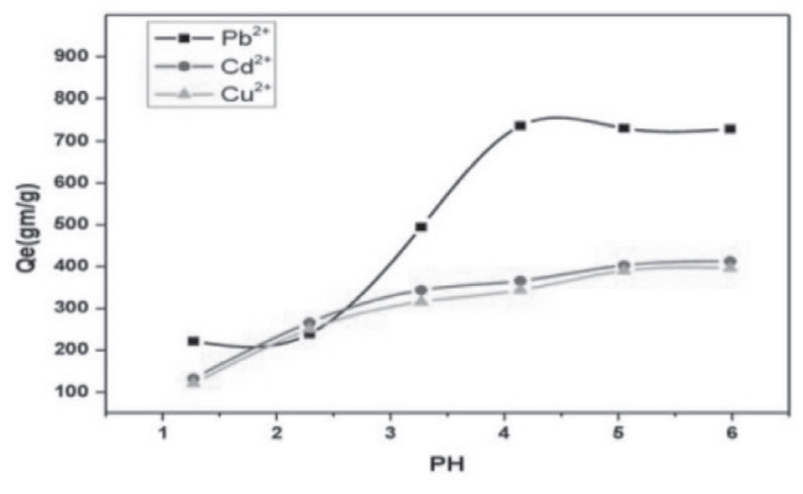

Fig. 2. Effect of $\mathrm{pH}$ on adsorption of $\mathrm{Cu}$ (II), $\mathrm{Cd}$ (II) and $\mathrm{Pb}$ (II) on modified PAN-g-GA [77].

wastes, sea nodule residue, tea factory waste, battery industry waste, areca waste, coffee husks, sugar beet pulp, red mud and iron (III) hydroxide, lignin, waste slurry, fly ash and blast furnace sludge [9]. Adsorption of $\mathrm{Cu}, \mathrm{Cd}$ and $\mathrm{Cr}$ was investigated with various potential agricultural and commercial adsorbents. Maximum Cr removal potential is $201.2 \mathrm{mg} / \mathrm{g}$ (with $\alpha$-ketoglutaric acid-modified magnetic chitosan), $160 \mathrm{mg} / \mathrm{g}$ (with PEI functionalized eggshell), $2,859.38 \mathrm{mg} / \mathrm{g}$ (with graphene sand composite) and $264.5 \mathrm{mg} / \mathrm{g}$ (with composite of activated alumina and carbon nanotubes); that for $\mathrm{Cd}$ was found to be $285.7 \mathrm{mg} / \mathrm{g}$ (with green coconut shell powder), $108.7 \mathrm{mg} / \mathrm{g}$ (with chitosan-coated ceramic alumina), $2838.7 \mathrm{mg} / \mathrm{g}$ (with $\mathrm{NaX}$ nanozeolite), $48.1 \mathrm{mg} / \mathrm{g}$ (with electrospun nanofibre membrane of $\mathrm{PEO} /$ chitosan), $256.41 \mathrm{mg} / \mathrm{g}$ (with chitosan/ $\mathrm{TiO}_{2}$ composite) and $200 \mathrm{mg} / \mathrm{g}$ (with succinic anhydride modified olive stones). The adsorption potential for $\mathrm{Cu}$ was found to be $1,602 \mathrm{mg} / \mathrm{g}$ (Paenibacillus polymyxa bacteria) and $285.7 \mathrm{mg} / \mathrm{g}$ (green coconut shell powder). The optimum $\mathrm{pH}$ values were observed to be in the ranges of 4.5-6, 4-7 and 1-2 for $\mathrm{Cu}, \mathrm{Cd}$ and $\mathrm{Cr}$, respectively; the optimum contact time was 120 minutes - 12 hours for maximum copper remova 1, 5-120 minutes for $\mathrm{Cd}$ and 120-9,900 minutes for chromium. For adsorbent dose, the optimum value was lying in a range of $0.75-10 \mathrm{~g} / \mathrm{L}$ [12].

Industrial electroplating wastewater was subjected to heavy metal removal $(\mathrm{Zn}, \mathrm{Fe}, \mathrm{Cu}, \mathrm{Ni}$, $\mathrm{Cd}, \mathrm{Cr}, \mathrm{Pb}$ and $\mathrm{As}$ ) by using two nano-adsorbents namely polyhydroxylbutyrate functionalized carbon nanotubes (PHB-CNTs) and purified carbon nanotubes (P-CNTs). The experiments were performed at a $\mathrm{pH}$ of 5.63-5.65, optimum dosage of $20 \mathrm{mg}$, equilibrium time of 70 minutes and optimum contact time of 10 minutes. The removal capacities of heavy metals were found in an order of PHB-CNTs $>$ P-CNTs based on electrostatic forces and ion exchange mechanism [75]. Commercial sodium alginate can be acidified with alcoholic $\mathrm{HCl}$ to change into water-insoluble form which is used to remove $\mathrm{Zn}$ (II) ions from wastewater [20]. Copper is adsorbed to the extent of $4.24 \mathrm{mg} / \mathrm{g}$ by using bioadsorbents including coconut cake powders $(1.0 \mathrm{~g})$, sesame seed cake powder $(1.0 \mathrm{~g})$ and groundnut seed cake power $(0.75 \mathrm{~g})$. The process was optimized at $40^{\circ} \mathrm{C}, 5 \mathrm{pH}, 10 \mathrm{mg} / \mathrm{L}$ initial metal concentration and 30 minutes contact time [76].

The modified PAN-g-GA was investigated for adsorption of $\mathrm{Cu}(\mathrm{II}), \mathrm{Cd}(\mathrm{II})$ and $\mathrm{Pb}(\mathrm{II})$; the adsorption capacity was found to depend upon the $\mathrm{pH}$ (Fig. 2), contact time and initial concentration of metal ions. The PAN-g-GA was obtained by graft polymerization of polyacrylonitrile (PAN) with arabic gum (AG); it was chemically modified by treating with hydrazine hydrochloride followed by hydrolysis in the basic medium [77].

Table 4 shows some low-cost industrial adsorbents and the respective metals which can be removed. Table 5 compares the economic analysis of heavy metals removal technologies.

Table 4. Some low-cost industrial adsorbents and the respective metals which can be removed.

\begin{tabular}{|c|c|}
\hline Adsorbent & Performance \\
\hline Waste rubber tire & $\begin{array}{l}\text { The mesoporous RTAC (a novel carbon prepared from waste tire rubber by physical activation) is very } \\
\text { helpful due to its enhanced batch adsorption capacity for } \mathrm{Ni} \text { and } \mathrm{Pb} \text { ions as compared to microporous } \\
\text { commercial carbon [78]. The waste tires (activated by thermally treatment) are used to manufacture } \\
\text { activated carbon which acts as a potential adsorbent for } \mathrm{Cr}(\mathrm{III}) \text { under optimized conditions of pH, adsorbent } \\
\text { dosage, contact time and initial concentration [79]. }\end{array}$ \\
\hline Waste slurry & Waste slurry is used to remove the metals ions like of $\mathrm{Pb}^{2+}, \mathrm{Hg}^{2+}$, and $\mathrm{Cr}^{6+}(030,560,540 \mathrm{mg} / \mathrm{g})$ [31] \\
\hline $\begin{array}{l}\text { Lignin-a black } \\
\text { liquor waste of paper } \\
\text { industry }\end{array}$ & $\begin{array}{l}\text { Lignin can remove up to } 63 \% \mathrm{Cr}^{+6} \text { and } 100 \% \mathrm{Cr}^{+3} \text { from an aqueous medium [80]. } \mathrm{Ni}(\mathrm{II}), \mathrm{Zn}(\mathrm{II}), \mathrm{Cd}(\mathrm{II}) \text {, } \\
\mathrm{Cu}(\mathrm{II}) \text { and } \mathrm{Pb}(\mathrm{II}) \text { are adsorbed on lignin isolated from black liquor (a waste material formed in paper } \\
\text { industry). The metal removal tendency of lignin is } \mathrm{Pb}(\mathrm{II})>\mathrm{Cu}(\mathrm{II})>\mathrm{Cd}(\mathrm{II})>\mathrm{Zn}(\mathrm{II})>\mathrm{Ni} \text { (II) [81] }\end{array}$ \\
\hline Coal fly & Coal fly can eliminate $\mathrm{Cu}, \mathrm{Mn}, \mathrm{Cd}, \mathrm{Pb}$ and $\mathrm{Zn}$ from municipal solid leachate [82]. \\
\hline $\begin{array}{l}\text { Red mud } \\
\text { (an aluminum } \\
\text { industry waste) }\end{array}$ & $\begin{array}{l}\text { Red mud waste material is commonly used to eliminate copper ions from contaminated water [83]. } \\
\text { It can be modified to eliminate zinc and cadmium ions from aqueous medium [84]. }\end{array}$ \\
\hline
\end{tabular}


Table 5. The economic comparisons of heavy metals removal technologies [86].

\begin{tabular}{|c|c|c|}
\hline Treatment & Advantages & Disadvantages from economic point of view \\
\hline Ion exchange & High regeneration of material, Metal selective & High maintenance and initial capital cost \\
\hline Chemical precipitation & Non-metal selective, simple operation & $\begin{array}{c}\text { High cost of disposal sludge, Large production of } \\
\text { sludge }\end{array}$ \\
\hline Membrane filtration & $\begin{array}{c}\text { Almost no chemical consumption, very little } \\
\text { formation of solid waste }\end{array}$ & $\begin{array}{c}\text { Low flow rate, High maintenance and initial } \\
\text { capital cost }\end{array}$ \\
\hline $\begin{array}{c}\text { Electrochemical } \\
\text { treatment }\end{array}$ & $\begin{array}{c}\text { Metal selective, } \\
\text { Potential treat effluent }>2000 \mathrm{mg} \mathrm{dm} \mathrm{dm}^{3}\end{array}$ & High inital cost \\
\hline Adsorption & $\begin{array}{c}\text { Low-cost, easy availability, high efficiency, design } \\
\text { flexibility and eco-friendly nature }\end{array}$ & No cost disadvantages. It is cost affective process \\
\hline
\end{tabular}

Table 6. Cost comparison of various adsorbents used for the removal of heavy metals from wastewater [85].

\begin{tabular}{|c|c|c|c|c|c|c|c|}
\hline Species & Type of adsorbent & $\begin{array}{c}\text { Optimum } \\
\text { dose } \\
\mathrm{g} / \mathrm{L}\end{array}$ & $\begin{array}{c}\text { Initial metal } \\
\text { concentration } \\
\mathrm{mg} / \mathrm{L}\end{array}$ & $\begin{array}{l}\text { Optimum } \\
\text { pH }\end{array}$ & $\begin{array}{c}\text { Adsorption } \\
\text { capacity } \\
\mathrm{mg} / \mathrm{g}\end{array}$ & $\begin{array}{c}\text { Retail } \\
\text { price } \\
\text { USS/kg }\end{array}$ & Ref. \\
\hline \multirow{3}{*}{$\mathrm{Cr}(\mathrm{VI})$} & AS-received CSC & 24 & 20 & 6.0 & 2.18 & 0.25 & \multirow{3}{*}[31]{} \\
\hline & CSC coated with chitosan & 18 & 20 & 4.0 & 3.65 & 0.25 & \\
\hline & $\mathrm{HNO}_{3}$-treated CSC & 12 & 20 & 4.0 & 10.88 & 0.25 & \\
\hline $\begin{array}{l}\mathrm{Cu}(\mathrm{II}), \mathrm{Cd}(\mathrm{II}), \\
\mathrm{Zn}(\mathrm{II})\end{array}$ & $\begin{array}{l}\text { Peanut hulls (agricultural } \\
\text { waste) }\end{array}$ & 10 & 32 & N.A & 10.17 & 2.0 & [87] \\
\hline $\begin{array}{l}\mathrm{Cu}(\mathrm{II}), \mathrm{Cd}(\mathrm{II}), \\
\mathrm{Zn}(\mathrm{II})\end{array}$ & $\begin{array}{l}\text { Peanuts hulls pellets (modi- } \\
\text { fied agricultural waste) }\end{array}$ & 10 & 32 & N.A & 9.11 & $\begin{array}{l}11.0- \\
18.5\end{array}$ & [87] \\
\hline $\mathrm{Cr}$ (IV) & $\begin{array}{l}\text { As-received Zeolite (natural } \\
\text { material) }\end{array}$ & 27 & 20 & 4.5 & 1.79 & 0.75 & [88] \\
\hline Ni (II) & $\begin{array}{c}\text { Activated slug } \\
\text { (Industrial by-product) }\end{array}$ & N.A & 248 & N.A & 66 & 0.038 & [89] \\
\hline
\end{tabular}

*N.A: Not Applicable

\section{Economic Comparison of Adsorption with Conventional Treatment Methods}

Adsorption is a cost effective method as compared to other conventional treatment methodologies. Table 5 represents an economic comparison between adsorption and other treatment procedures. Table 6 demonstrates cost comparison of various adsorbents used for the removal of heavy metals from wastewater [85].

\section{Conclusions}

Heavy metals e.g., $\mathrm{Hg}, \mathrm{Cd}, \mathrm{Cr}, \mathrm{Pb}, \mathrm{Zn}$, As and $\mathrm{Ni}$, etc. have a greater tendency to be accumulated in aqueous water and create disturbances in the food chain. They are highly difficult to remove and cause adverse effects on blood composition, lungs, energy level, kidneys, central nervous system, liver, and other vital organs. Adsorption is a cheapest and excellent technique for removal of heavy metal ions from wastewater and is advantageous due to easily accessible favorable conditions as well as local and abundant availability of required resources. It involves low-cost adsorbents of industrial (e.g., waste slurry, fly ash, sugar cane bagasse, lignin, red mud, blast furnace slag, sugar beet pulp etc.), natural (e.g., zeolite) and agricultural (e.g., rice, wool, waste tea, coffee, crop biomass, waste tea, rice straw, rice hulls, coconut shell, soybean hull, papaya wood, peanut shell, and citrus fruits) origin. Adsorption may be classified into a continuous batch, semi-batch, and batch categories or into physical and chemical adsorption. The adsorbates bind on to the surface of adsorbents due to van der Waals forces in physical adsorption. In chemical or activated adsorption, adsorbent and adsorbates chemically react with each other.

\section{Conflict of Interest}

The authors declare no conflict of interest. 


\section{References}

1. GHANI A., QAYYUM I., HUSSAIN S., RIAZ M., SADDIQA A. Evaluation of Hardness of Ground Drinking Water in Vehari, Pakistan. Int. J. Econ. Env. Geol., 10, 84, 2019.

2. AMBREEN H., HUSSAIN S., NAEEM N., AHMAD A., RIAZ M., SADDIQA A. Biological and Chemical Strategies for the Treatment of Sugar Industry Effluents. Int. J. Econ. Env. Geol., 10, 59, 2019.

3. SINGH S., KUMAR V., DATTA S., DHANJAL D. S., SHARMA K., SAMUEL J., SINGH J. Current advancement and future prospect of biosorbents for bioremediation. Sci. Total Environ., 135895, 2019.

4. ULLAH H., HUSSAIN S., AHMAD A. Study on Arsenic Poisoning by Worldwide Drinking Water, its Effects and Prevention. Int. J. Econ. Env. Geol., 10, 72, 2019.

5. REHMAN H., ALI Z., HUSSAIN M., GILANI S.R., SHAHZADY T.G., ZAHRA A., HUSSAIN S., HUSSAIN, H., HUSSAIN I., FAROOQ M.U. Synthesis and characterization of $\mathrm{ZnO}$ nanoparticles and their use as an adsorbent for the arsenic removal from drinking water. Dig. J. Nanomater. Bios., 14, 1033, 2019.

6. CHAUDHARI M., HUSSAIN S., REHMAN H., SHAHZADY T.G. A perspective Study on Lead Poisoning: Exposure, Effects and Treatment. Int. J. Econ. Env. Geol., 10, 70, 2019.

7. BOBADE V., ESHTIAGI N. Heavy metals removal from wastewater by adsorption process: A review. Asia Pacific Confederation of Chemical Engineering Congress 2015: APCChE 2015, incorporating CHEMECA 2015. Engineers Australia., 312, 2015.

8. WOŁOWIEC M., KOMOROWSKA-KAUFMAN M., PRUSS A., RZEPA G., BAJDA T. Removal of Heavy Metals and Metalloids from Water Using Drinking Water Treatment Residuals as Adsorbents: A Review. Minerals., 9, 487, 2019.

9. TRIPATHI A., RANJAN M.R. Heavy metal removal from wastewater using low cost adsorbents. J. Bioremed. Biodeg., 6, 1, 2015.

10. AMBREEN R., HUSSAIN S., SARFRAZ S. Anaerobic Biotechnology for Industrial Wastewater Treatment. Int. J. Econ. Env. Geol., 9, 61, 2018.

11. BOLISETTY S., PEYDAYESH M., MEZZENGA R. Sustainable technologies for water purification from heavy metals: review and analysis. Chem. Soc. Rev., 48, 463, 2019.

12. AGARWAL M., SINGH K. Heavy metal removal from wastewater using various adsorbents: a review. J. Water Reuse Desal., 7, 387, 2017.

13. INOUE K. Heavy metal toxicity. J. Clinic. Toxicol. S., 3, 2161, 2013.

14. ABDEL-RAOUF M., ABDUL-RAHEIM A. Removal of Heavy Metals from Industrial Waste Water by BiomassBased Materials: A Review. Journal of pollution Effects and Control., 5, 180, 2017.

15. KUMAR S., SHARMA A. Cadmium toxicity: effects on human reproduction and fertility. Rev. Environ. Health., 34, 327, 2019.

16. JAN A., AZAM M., SIDDIQUI K., ALI A., CHOI I., HAQ Q. Heavy metals and human health: mechanistic insight into toxicity and counter defense system of antioxidants. Int. J. Mol. Sci., 16, 29592, 2015.

17. LAKHERWAL D. Adsorption of heavy metals: a review. IJERD., 4, 41, 2014
18. TAYLOR A.A., TSUJI J.S., GARRY M.R., MCARDLE M.E., GOODFELLOW W.L., ADAMS W.J., MENZIE C.A. Critical Review of Exposure and Effects: Implications for Setting Regulatory Health Criteria for Ingested Copper. Environ. Manage., 65, 131, 2020.

19. BUXTON S., GARMAN E., HEIM K.E., LYONSDARDEN T., SCHLEKAT C.E., TAYLOR M.D., OLLER A.R. Concise review of nickel human health toxicology and ecotoxicology. Inorganics., 7, 89, 2019.

20. ABDEL-HALIM E., AL-DEYAB S.S. Removal of heavy metals from their aqueous solutions through adsorption onto natural polymers. Carbohydr. Polym., 84, 454, 2011.

21. FATTA-KASSINOS D., DIONYSIOU D.D., KÜMMERER $\mathrm{K}$. Advanced treatment technologies for urban wastewater reuse. Springer International Publishing Switzerland. 2016.

22. SALEHZADEH J. Removal of Heavy Metals $\mathrm{Pb} 2, \mathrm{Cu} 2$, Zn 2, Cd 2, Ni 2, Co 2 and Fe 3 from Aqueous Solutions by using Xanthium Pensylvanicum. Leonardo J. Sci., 23, 97, 2013.

23. ALFARRA R.S., ALI N.E., YUSOFF M.M. Removal of heavy metals by natural adsorbent. Int. J. Biosci., 4, 2014.

24. ANSARI A., VAHEDI S., TAVAKOLI O., KHOOBI M., FARAMARZI M.A. Novel $\mathrm{Fe}_{3} \mathrm{O}_{4} /$ hydroxyapatite/ $\beta$ cyclodextrin nanocomposite adsorbent: Synthesis and application in heavy metal removal from aqueous solution. Appl. Organomet. Chem., 33, 1, 2019.

25. ABLOUH E.-H., HANANI Z., ELADLANI N., RHAZI M., TAOURIRTE M. Chitosan microspheres/sodium alginate hybrid beads: an efficient green adsorbent for heavy metals removal from aqueous solutions. Sustain. Environ. Res., 29, 1, 2019.

26. HAQ F., YU H., WANG L., TENG L., HAROON M., KHAN R.U., MEHMOOD S., ULLAH R.S., KHAN A., NAZIR A. Advances in chemical modifications of starches and their applications. Carbohydr. Res., 476, 12, 2019.

27. TORRES-CABAN R., VEGA-OLIVENCIA C.A., MINACAMILDE N. Adsorption of $\mathrm{Ni}^{2+}$ and $\mathrm{Cd}^{2+}$ from Water by Calcium Alginate/Spent Coffee Grounds Composite Beads. Applied Sciences., 9, 4531, 2019.

28. NGOMSIK A.-F., BEE A., SIAUGUE J.-M., TALBOT D., CABUIL V., COTE G. Co (II) removal by magnetic alginate beads containing Cyanex 272. J. Hazard Mater., 166, 1043, 2009.

29. NANDAL M., HOODA R., DHANIA G. Tea wastes as a sorbent for removal of heavy metals from wastewater. Int. J. Curr. Eng. Technol., 4, 244, 2014.

30. LEE S.-J., PARK J.H., AHN Y.-T., CHUNG J.W. Comparison of heavy metal adsorption by peat moss and peat moss-derived biochar produced under different carbonization conditions. Water, Air, Soil Pollut., 226, 1, 2015.

31. BABEL S., KURNIAWAN T.A. Low-cost adsorbents for heavy metals uptake from contaminated water: a review. J. Hazard Mater., 97, 219, 2003.

32. BELOVA T. Adsorption of heavy metal ions $\left(\mathrm{Cu}^{2+}, \mathrm{Ni}^{2+}\right.$, $\mathrm{Co}^{2+}$ and $\mathrm{Fe}^{2+}$ ) from aqueous solutions by natural zeolite. Heliyon., 5, 1, 2019.

33. OUYANG D., ZHUO Y., HU L., ZENG Q., HU Y., HE Z. Research on the Adsorption Behavior of Heavy Metal Ions by Porous Material Prepared with Silicate Tailings. Minerals., 9, 291, 2019.

34. KHAN A., ALI N., BILAL M., MALIK S., BADSHAH, S., IQBAL H. Engineering Functionalized Chitosan-Based Sorbent Material: Characterization and Sorption of Toxic Elements. Appl. Sci., 9, 5138, 2019. 
35. YANG K., WANG G., LIU F., WANG X., CHEN $\mathrm{X}$. Removal of multiple heavy metal ions using a macromolecule chelating flocculant xanthated chitosan. Water Sci. Technol., 79, 2289, 2019.

36. MANZOOR K., AHMAD M., AHMAD S., IKRAM S. Removal of $\mathrm{Pb}$ (II) and $\mathrm{Cd}$ (II) from wastewater using arginine cross-linked chitosan-carboxymethyl cellulose beads as green adsorbent. RSC advances., 9, 7890, 2019.

37. ALTUN T. Chitosan-coated sour cherry kernel shell beads: an adsorbent for removal of $\mathrm{Cr}$ (VI) from acidic solutions. J. Anal. Sci. Technol., 10, 14, 2019.

38. UGWU I.M., IGBOKWE O.A. Sorption of heavy metals on clay minerals and oxides: a review. Advanced Sorption Process Applications. IntechOpen, 2019.

39. STYLIANOU M.A., INGLEZAKIS V.J., MOUSTAKAS K.G., MALAMIS S.P., LOIZIDOU M.D. Removal of $\mathrm{Cu}$ (II) in fixed bed and batch reactors using natural zeolite and exfoliated vermiculite as adsorbents. Desalination., 215, 133, 2007.

40. DOĞAN M., TURHAN Y., ALKAN M., NAMLI H., TURAN P., DEMIRBAŞ Ö. Functionalized sepiolite for heavy metal ions adsorption. Desalination., 230, 248, 2008.

41. INDAH S., HELARD D., PRIMASARI B., EDWIN T., PUTRA, R. H. Modification of natural pumice by physical and chemical treatments for removal of zinc ions from aqueous solution. MATEC Web of Conferences. EDP Sciences, 06009, 2019.

42. NGUYEN K.M., NGUYEN B.Q., NGUYEN H.T., NGUYEN H.T. Adsorption of arsenic and heavy metals from solutions by unmodified iron-ore sludge. Appl. Sci., 9, 619, 2019.

43. WANG J., CHEN C. Biosorbents for heavy metals removal and their future. Biotechnol. Adv., 27, 195, 2009.

44. OKORO I., OKORO S. Agricultural by products as green chemistry absorbents for the removal and recovery of metal ions from waste-water environments. C.J.W.A.S.P., 2, 15, 2011

45. SULYMAN M., NAMIESNIK J., GIERAK A. Low-cost Adsorbents Derived from Agricultural By-products/Wastes for Enhancing Contaminant Uptakes from Wastewater: A Review. Pol. J. Environ. Stud., 26, 479, 2017.

46. KANAMARLAPUDI S., CHINTALPUDI V.K., MUDDADA S. Application of biosorption for removal of heavy metals from wastewater. Biosorption., 18, 69, 2018.

47. MATHEW B.B., JAISHANKAR M., BIJU V.G., BEEREGOWDA K.N. Role of bioadsorbents in reducing toxic metals. J. Toxicol., 2016, 1, 2016.

48. BHATTACHARYA A.K., VENKOBACHAR C. Removal of cadmium (II) by low cost adsorbents. J. Environ. Eng., 110, 110, 1984

49. ALSLAIBI T., ISMAIL A., MOHD A.A., AHMED A.F. Heavy metals removal from wastewater using agricultural wastes as adsorbents: a review. Int. J. Chem. Environ. Eng., 5, 7, 2014.

50. KHAN N.A., IBRAHIM S., SUBRAMANIAM P. Elimination of heavy metals from wastewater using agricultural wastes as adsorbents. Malays. J. Sci., 23, 43, 2004.

51. ORHAN Y., BÜYÜKGÜNGÖR H. The removal of heavy metals by using agricultural wastes. Water Sci. Technol., 28, 247, 1993.

52. ESMAEL A.I., MATTA M.E., HALIM H.A., AZZIZ F.M.A. Adsorption of heavy etals from industrial wastewater using palm date pits as low cost adsorbent. Int. J. Eng. Adv. Technol., 3, 71, 2014.
53. ZAKARIA Z., HISAM E.A., ROFIEE M., NORHAFIZAH M., SOMCHIT M., TEH L., SALLEH M. In vivo antiulcer activity of the aqueous extract of Bauhinia purpurea leaf. J. Ethnopharmacol., 137, 1047, 2011.

54. SALAM O.E.A., REIAD N.A., ELSHAFEI M.M. A study of the removal characteristics of heavy metals from wastewater by low-cost adsorbents. J. Adv. Res., 2, 297, 2011.

55. ZWAIN H.M., VAKILI M., DAHLAN I. Waste material adsorbents for zinc removal from wastewater: a comprehensive review. Int. J. Chem. Eng., 2014, 1, 2014.

56. BAYUO J., PELIG-BA K.B., ABUKARI M.A. Adsorptive removal of chromium (VI) from aqueous solution unto groundnut shell. Appl. Water Sci., 9, 107, 2019.

57. SING K., WAZIRI S.A. Activated carbons precursor to corncob and coconut shell in the remediation of heavy metals from oil refinery wastewater. $J$. Mate. Environ. Sci., 10, 657, 2019.

58. BOULAICHE W., HAMDI B., TRARI M. Removal of heavy metals by chitin: equilibrium, kinetic and thermodynamic studies. Appl. Water Sci., 9, 39, 2019.

59. JIANG X., FAN W., LI C., WANG Y., BAI J., YANG H., LIU X. Removal of $\mathrm{Cr}(\mathrm{VI})$ from wastewater by a twostep method of oxalic acid reduction-modified fly ash adsorption. RSC Advances., 9, 33949, 2019.

60. HEGAZI H.A. Removal of heavy metals from wastewater using agricultural and industrial wastes as adsorbents. HBRC journal., 9, 276, 2013.

61. MARSHALL W.E., CHAMPAGNE E.T. Agricultural byproducts as adsorbents for metal ions in laboratory prepared solutions and in manufacturing wastewater. J. Environ. Sci. Heal. A., 30, 241, 1995.

62. DUBEY S.P., GOPAL K. Adsorption of chromium(VI) on low cost adsorbents derived from agricultural waste material: A comparative study. J. Hazard. Mater., 145, 465, 2007.

63. WAN NGAH W.S., HANAFIAH M.A.K.M. Removal of heavy metal ions from wastewater by chemically modified plant wastes as adsorbents: A review. Bioresour. Technol., 99, 3935, 2008

64. MONDAL M.K. Removal of $\mathrm{Pb}(\mathrm{II})$ ions from aqueous solution using activated tea waste: Adsorption on a fixedbed column. J. Environ. Manage., 90, 3266, 2009.

65. BANERJEE K., RAMESH S., GANDHIMATHI R., NIDHEESH P., BHARATHI K. A novel agricultural waste adsorbent, watermelon shell for the removal of copper from aqueous solutions. Iran. J. Energy Environ., 3, 143, 2012.

66. MASSIE B., SANDERS T., DEAN L. Removal of heavy metal contamination from peanut skin extracts by waste biomass adsorption. J. Food Process. Eng., 38, 555, 2015.

67. INGLE P.K., ATTARKAR K., RATHOD V.K. Ultrasound assisted chemical activation of peanut husk for copper removal. Green Process. Synth., 8, 46, 2019.

68. AJMAL M., KHAN A.H., AHMAD S., AHMAD A. Role of sawdust in the removal of copper (II) from industrial wastes. Water Res., 32, 3085, 1998.

69. AJMAL M., RAO R.A.K., SIDDIQUI B.A. Studies on removal and recovery of $\mathrm{Cr}$ (VI) from electroplating wastes. Water Res., 30, 1478, 1996.

70. MARSHALL W.E., CHAMPAGNE E.T., EVANS W.J. Use of rice milling byproducts (hulls \& bran) to remove metal ions from aqueous solution. J. Environ. Sci. Health A., 28, 1977, 1993.

71. NGUYEN H.T., NGUYEN B.Q., DUONG T.T., BUI A.T., NGUYEN H.T., CAO H.T., MAI N.T., NGUYEN 
K.M., PHAM T.T., KIM K.-W. Pilot-Scale Removal of Arsenic and Heavy Metals from Mining Wastewater using Adsorption Combined with Constructed Wetland. Minerals., 9, 379, 2019.

72. WANG X., LI X., LIU G., HE Y., CHEN C., LIU X., LI G., GU Y., ZHAO Y. Mixed heavy metal removal from wastewater by using discarded mushroom-stick biochar: adsorption properties and mechanisms. Environ. Sci. Process. Impacts., 21, 584, 2019.

73. CHERDCHOO W., NITHETTHAM S., CHAROENPANICH J. Removal of $\mathrm{Cr}$ (VI) from synthetic wastewater by adsorption onto coffee ground and mixed waste tea. Chemosphere., 221, 758, 2019.

74. OBAYOMI K., BELLO J., NNORUKA J., ADEDIRAN A., OLAJIDE P. Development of low-cost bio-adsorbent from agricultural waste composite for $\mathrm{Pb}$ (II) and As (III) sorption from aqueous solution. Cogent Eng., 6, 1687274, 2019.

75. BANKOLE M.T., ABDULKAREEM A.S., MOHAMMED I.A., OCHIGBO S.S., TIJANI J.O., ABUBAKRE O.K., ROOS W.D. Selected heavy metals removal from electroplating wastewater by purified and polyhydroxylbutyrate functionalized carbon nanotubes adsorbents. Sci. Rep., 9, 1, 2019.

76. KUMAR G.P., MALLA K.A., YERRA B., RAO K.S. Removal of $\mathrm{Cu}$ (II) using three low-cost adsorbents and prediction of adsorption using artificial neural networks. Appl. Water Sci., 9, 44, 2019.

77. ELBEDWEHY A.M., ABOU-ELANWAR A.M., EZZAT A.O., ATTA A.M. Super Effective Removal of Toxic Metals Water Pollutants Using Multi Functionalized Polyacrylonitrile and Arabic Gum Grafts. Polymers., 11, 1938, 2019.

78. GUPTA V.K., GANJALI M.R., NAYAK A., BHUSHAN B., AGARWAL S. Enhanced heavy metals removal and recovery by mesoporous adsorbent prepared from waste rubber tire. Chem. Eng. J., 197, 330, 2012.

79. GUPTA V.K., ALI I., SALEH T.A., SIDDIQUI M., AGARWAL S. Chromium removal from water by activated carbon developed from waste rubber tires. Environ. Sci. Pollut. Res., 20, 1261, 2013.

80. LALVANI S., HUBNER A., WILTOWSKI T. Chromium adsorption by lignin. Energy sources., 22, 45, 2000.

81. GUO X., ZHANG S., SHAN X.-Q. Adsorption of metal ions on lignin. J. Hazard. Mater., 151, 134, 2008.

82. MOHAN S., GANDHIMATHI R. Removal of heavy metal ions from municipal solid waste leachate using coal fly ash as an adsorbent. J. Hazard. Mater., 169, 351, 2009.

83. NADAROGLU H., KALKAN E., DEMIR N. Removal of copper from aqueous solution using red mud. Desalination., 251, 90, 2010.

84. GUPTA V.K., SHARMA S. Removal of cadmium and zinc from aqueous solutions using red mud. Environ. Sci. Technol., 36, 3612, 2002.

85. KURNIAWAN T.A., CHAN G.Y.S., LO W.-H., BABEL S. Comparisons of low-cost adsorbents for treating wastewaters laden with heavy metals. Sci. Total Environ., 366, 409, 2006.

86. ABAS S.N.A., ISMAIL M.H.S., KAMAL M.L., IZHAR S. Adsorption process of heavy metals by low-cost adsorbent: a review. World Appl. Sci. J., 28, 1518, 2013.

87. BROWN P., JEFCOAT I.A., PARRISH D., GILL S., GRAHAM E. Evaluation of the adsorptive capacity of peanut hull pellets for heavy metals in solution. Adv. Environ. Res., 4, 19, 2000.

88. KURNIAWAN T., BABEL S. A research study on Cr (VI) removal from contaminated wastewater using low-cost adsorbents and commercial activated carbon. Second Int Conf on Energy Technology towards a Clean Environment (RCETE), 1110, 2003.

89. GUPTA V.K. Equilibrium uptake, sorption dynamics, process development, and column operations for the removal of copper and nickel from aqueous solution and wastewater using activated slag, a low-cost adsorbent. Ind. Eng. Chem. Res., 37, 192, 1998. 